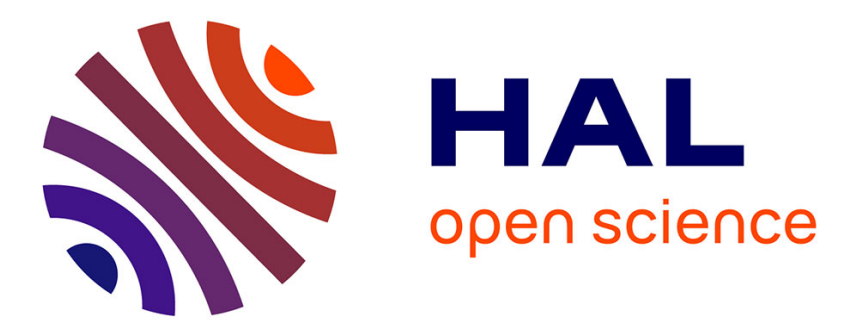

\title{
On the theoretical description of the early oxidation stages of copper by cw CO2 laser irradiation
}

I. Ursu, L. Nanu, I.N. Mihailescu, L.C. Nistor, V.S. Teodorescu, A.M. Prokhorov, V.I. Konov, N.I. Chapliev

\section{- To cite this version:}

I. Ursu, L. Nanu, I.N. Mihailescu, L.C. Nistor, V.S. Teodorescu, et al.. On the theoretical description of the early oxidation stages of copper by cw CO2 laser irradiation. Journal de Physique Lettres, 1984, 45 (14), pp.737-740. 10.1051/jphyslet:019840045014073700 . jpa-00232405

\section{HAL Id: jpa-00232405 https://hal.science/jpa-00232405}

Submitted on 1 Jan 1984

HAL is a multi-disciplinary open access archive for the deposit and dissemination of scientific research documents, whether they are published or not. The documents may come from teaching and research institutions in France or abroad, or from public or private research centers.
L'archive ouverte pluridisciplinaire HAL, est destinée au dépôt et à la diffusion de documents scientifiques de niveau recherche, publiés ou non, émanant des établissements d'enseignement et de recherche français ou étrangers, des laboratoires publics ou privés. 
Classification

Physics Abstracts

$81.60-42.60$

\title{
On the theoretical description of the early oxidation stages of copper by $\mathrm{cw} \mathrm{CO}_{2}$ laser irradiation
}

\author{
I. Ursu, L. Nanu, I. N. Mihăilescu, L. C. Nistor, V. S. Teodorescu \\ Central Institute of Physics, Bucharest, Romania
}

\author{
A. M. Prokhorov, V. I. Konov and N. I. Chapliev \\ Institute of General Physics, Moscow, U.S.S.R.
}

(Reçu le 12 mars 1984, révisé le 2 mai, accepté le 24 mai 1984)

\begin{abstract}
Résumé. - On étudie l'application des interprétations théoriques disponibles à l'analyse de nouvelles données expérimentales obtenues en étudiant les premières étapes de l'oxydation de cibles en cuivre sous irradiation laser $\mathrm{CO}_{2}$ continu.
\end{abstract}

\begin{abstract}
An analysis is performed concerning the application of the available theoretical interpretations in analysing the new experimental data obtained in the study of the early stages of the $\mathrm{cw}$ $\mathrm{CO}_{2}$ laser oxidation of copper targets.
\end{abstract}

\section{Introduction.}

The oxidation of metallic surfaces under the action of powerful laser radiation, in competition with the "cleaning effect " and at the same time with the induction of new defects, presents both current scientific interest and particular technological significance. Indeed, the coming out and the development of oxides leads to a substantial modification of the thermal and optical properties (first of all of the absorptivity and reflectivity) strongly determining the behaviour of the metallic components (mirrors, deflectors, etc.) when used in powerful laser systems. After several qualitative investigations [1-3], we have recently succeeded in measuring the thickness of the oxide layer induced during the early stages of the oxidation of copper monocrystalline targets by cw $\mathrm{CO}_{2}$ laser irradiation $[4,5]$. We have also recorded the irradiation time, the incident laser power and determined the temperature that is reached on the target surface.

To this end, we used a new, jet polishing method, proceeding from the unirradiated face of the target and protecting the oxide layer with a sticky tape [4].

We have recently developed a new method for determining the thickness of the oxide layer. Thus, as previously reported [3,4], the oxidę layer grown on the copper samples surface as a result of $\mathrm{cw} \mathrm{CO}_{2}$ laser irradiation shows a poor adherence to the metallic support and is rather likely to break. Therefore, when scratching the oxidized target surface with a fine needle, the oxide cracks in small plates (like ice on the water). By scanning electron microscopy at high magni- 
fication and a proper tilting of the sample we determined the thickness directly by measuring the edge width of the oxide plates. Further details on this technique will be given in a next paper of ours [5].

In this Letter, we consider the possibility of applying the available theoretical interpretations in analysing such new quantitative results on the evolution of the oxidation process induced and controlled under the action of laser radiation.

\section{Laser heating.}

Small plates of polycrystalline $\mathrm{Cu}$ of $(5 \times 5 \times 0.3) \mathrm{mm}^{3}$ mechanically or electrochemically polished; freshly cleaned with alcohol were irradiated with a TEMoo power stabilized cw $\mathrm{CO}_{2}$ laser. The laser output beam of $\approx 30 \mathrm{~W}$ was practically covering the whole surface of the plates. The variation of the samples' temperature and its derivative were followed with the aid of built-in chromel-alumel thermocouples. The targets absorptivity variation of the $10.6 \mu \mathrm{m}$ radiation was then inferred according to the procedure described in [7]. If the thermal constants of copper are considered, one can check out that the temperature inside the samples gets uniform in a time interval which is negligible as compared to the irradiation durations of hundreds and thousands of seconds. In any case, the recorded values of the temperature are in good keeping with the inferred evolution of the absorptivity.

A typical recording of the sample temperature evolution during irradiation is given in figure 1. As one may see, the temperature saturates rather rapidly (a few seconds) and remains almost constant for the rest of the irradiation.

\section{Laser oxidation.}

The oxide thickness, $x$, as established by the earlier mentioned techniques $[4,5]$, is given in table $\mathrm{I}$, together with the corresponding irradiation times, $t$, and the value of the temperature reached in the target as a result of laser irradiation, $T$.

On the other hand, SAD studies pointed $\mathrm{Cu}, \mathrm{O}$ as the only oxide grown onto the irradiated target surface.

We emphasize from the beginning that the mere application of the available theoretical treatments to the initial stages of the laser oxidation of copper appears to be quite unsatisfactory.

Thus, the Wagner theory [6] according to which the thickness of the oxide layer, $x$, is evoluating as

$$
\frac{\mathrm{d} x}{\mathrm{~d} t}=\frac{d_{0}}{x} \exp \left(-\frac{T_{\mathrm{D}}}{T}\right),
$$

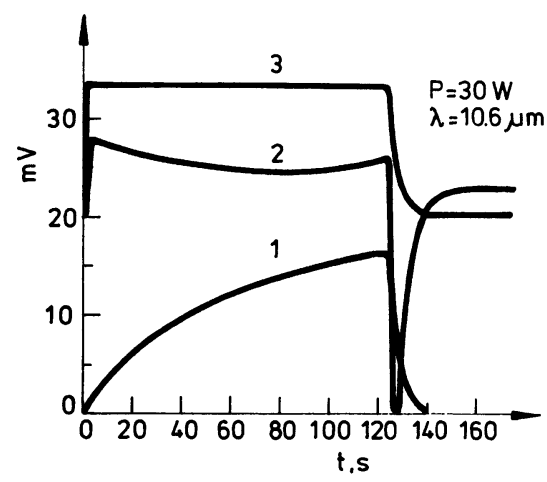

Fig. 1. - T ypical recording of the temperature (1), its derivative (2) and of the laser power (3), during the irradiation of the $\mathrm{Cu}$ plates. 
Table I. - Experimental and calculated oxide thickness values.

\begin{tabular}{|l|l|r|r|r|r|r|}
\hline Nr. & \multicolumn{1}{|c|}{ Sample's surface state [3] } & $t(\mathrm{~s})$ & $T\left({ }^{\circ} \mathrm{C}\right)$ & $x(\AA)$ & $x_{1}(\AA)$ & $x_{2}(\AA)$ \\
\hline 1 & mechanically polished & 660 & 155 & $400-600$ & 285 & 60 \\
2 & electrochemically polished & 660 & 195 & $500-680$ & 660 & 275 \\
3 & mechanically polished & 1140 & 210 & $600-800$ & 1050 & 610 \\
4 & mechanically polished & 1140 & 210 & $600-1000$ & 1050 & 610 \\
5 & electrochemically polished & 1200 & 228 & $800-1000$ & 1465 & 1110 \\
6 & mechanically polished & 1440 & 220 & $1000-1300$ & 1360 & 945 \\
7 & mechanically polished & 1540 & 260 & $1200-1800$ & 1870 & 1885 \\
\hline
\end{tabular}

where $d_{0}$ and $T_{\mathrm{D}}$ are thermodiffusive constants, applies only for $x \gtrsim 1000 \AA$, while we mainly recorded in the (500-1 000) $\AA$ range $[4,5]$. Therefore when evaluating $x$ from equation (1) using the " non laser » constants $d_{0} \simeq 0.299 \mathrm{~cm}^{2} / \mathrm{s}, T_{\mathrm{D}} \approx 18800 \mathrm{~K}$ and assuming $a$ constant temperature during the irradiation process (as pointed before), one obtains a value of $x 30$ times smaller than the experimental one.

On the other hand, the Wagner-Valensi approach [6] which takes the complex structure of the oxide film into account is also unsuitable as it predicts the advantageous growth of $\mathrm{CuO}$ during the early oxidation stages, which sharply contradicts our experimental evidence [4].

However, if in equation (1) we use the « laser » values of the thermodiffusive constants which we established in [7], by processing the variation curves of the sample's temperature and its derivative during laser irradiation, i.e. $d_{0}=1.4 \mathrm{~cm}^{2} / \mathrm{s}$ and $T_{\mathrm{D}}=15500 \mathrm{~K}$, a much better agreement with the experimental results is to be pointed out, as one can notice from table I ( $x_{1}$ values).

Finally we stopped at the Cabrera-Mott theory [6,8], which is known to refer to the thin oxide film growth, covering a rather large thickness range for the oxide layer from (50-100) $\AA$ up to several hundreds of $\AA$ (as recorded in our case). Thus, as experimentally confirmed by « classical » oxidation experiments [9], a cubic growth rate law seems to be most appropriate in describing copper oxidation in the $(100-250)^{\circ} \mathrm{C}$ range

$$
\frac{\mathrm{d} x}{\mathrm{~d} t}=\frac{d_{1}}{x^{2}} \exp \left(-\frac{T_{1}}{T}\right) .
$$

The values calculated with the above equation, where $d_{1}=10^{-7} \mathrm{~cm}^{2} / \mathrm{s}, T_{1} \simeq 12755 \mathrm{~K}$, were also given in the table ( $x_{2}$ values).

Upon studying table $\mathrm{I}$, one can conclude that there is a generally good agreement between the experimentally inferred values of the oxide layer thickness grown in early stages onto the surface of copper targets as a result of $\mathrm{cw} \mathrm{CO}_{2}$ laser irradiation, and the predictions of equation (1) and (2). More particularly, values of $x_{1}$ appear to describe better the experimental evidence corresponding to the shortest irradiation durations in our experiments, while values of $x_{2}$ grow more and more appropriate as the irradiation time rises.

Further developments are therefore necessary in our opinion in order to get a unitary, fully adequate theoretical description of the early oxidation process evolution of copper (and generally metallic) samples under laser irradiation. To this effect a much larger set of direct experimental data should be available. New experiments devoted to this aim are now in progress, including a comparison of the oxide growth kinetics under laser irradiation with the kinetics associated with a furnace heating under identical conditions. 


\section{References}

[1] Ursu, I., Mihăilescu, I. N., Nistor, L. C., Teodorescu, V. S., Prokhorov, A. M., Chapliev, N. I., Konov, V. I., Ralchenko, V. G., Tokarev, V. N., Appl. Phys. A 29 (1982) 209.

[2] Ursu, I., Apostol, I., Mihăllescu, I. N., Nistor, L. C., Teodorescu, V. S., Prokhorov, A. M., Konov, V. I., Chapliev, N. I., in Surface Studies with Lasers, Springer Series in Chemical Physics, vol. 33 ; Eds., Aussenegg, F. R., Leitner, A., Lippitsch, M. E. (Springer Verlag, Berlin, Heidelberg, NY, Tokyo) 1983, p. 234.

[3] Ursu, I., Apostol, I., Crăciun, D., Dinescu, M., Mihăilescu, I. N., Nistor, L. C., Teodorescu, V. S., Prokhorov, A. M., Chapliev, N. I., Konov, V. I., J. Phys. D 17 (1984) 747.

[4] Ursu, I., Nistor, L. C., Teodorescu, V. S., Mihăilescu, I. N., Apostol, I., Nanu, L., Prokhorov, A. M., Chapliev, N. I., Konov, V. I., Tokarev, V. N., Ralchenko, V. G., 1983 SPIE Technical Conference Geneva, paper 398-69, published in Industrial Applications of Laser Technology (SPIE Eds.) 1983, p. 398.

[5] Úrsu, I., Mihăilescu, I. N., Apostol, I., Nistor, L. C., Teodorescu, V. S., Nanu, L., Prokhorov, A. M., Konov, V. I., Chapliev, N. I., Ralchenko, V. G., Tokarev, V. N., to be published in Appl. Phys. A (1984).

[6] Kubaschewski, O., Hopkins, B. E., Oxidation of Metals and Alloys (Butterworth, London) 1962.

[7] Arzuov, M. I., Karasev, M. E., Konov, V. I., Kostin, V. V., Metev, S. M., Silenok, A. S., Chapliev, V. I., Sov. J. Quantum Electron. $8(1978) 892$.

[8] Cabrera, N., Mott, W. F., Rep. Progr. Phys. 12 (1948/1949) 163.

[9] Campbell, W. E., Thomas, U. B., Trans. Electrochem. Soc. 91 (1947) 623. 